\title{
Penerapan Keselamatan Dan Kesehatan Kerja Rumah Sakit (K3RS) di Rumah Sakit Umum X Jakarta
}

\author{
Suprapto', Affan Ahmad ${ }^{2}$ \\ 1,2 Program Sarjana Kesehatan Masyarakat \\ Sekolah Tinggi Ilmu Kesehatan Indonesia Maju \\ Jln. Harapan No.50, Lenteng Agung - Jakarta Selatan 12610 \\ Telp: (021) 78894045, Email: 룰.21597@gmail.com, ${ }^{2}$ affanahmad@gmail.com
}

Editor:

Hak Cipta:

(C)2021 Artikel ini memiliki akses terbuka dan dapat didistribusikan berdasarkan ketentuan Lisensi Atribusi Creative Commons, yang memungkinkan penggunaan, distribusi, dan reproduksi yang tidak dibatasi dalam media apa pun, asalkan nama penulis dan sumber asli disertakan. Karya ini dilisensikan di bawah Lisensi Creative Commons Attribution Share Alike 4.0 Internasional.

\begin{abstract}
A B S T R A C T
Introduction: Hospital as a health service institution for the community is a workplace that has a high risk to the safety and health of hospital human resources, patients, patient companions, visitors, and hospital environment so that the hospital is obliged to implement the Republic of Indonesia Ministerial Regulation No. 66 of 2016 concerning Hospital Work Safety and Health Standards.

Objectives: The purpose of this study was to determine the Implementation of Occupational Safety and Health Standards at the Jagakarsa Regional Hospital in 2019.

Method: This type of research is qualitative using 5 informants.

Result: From the results of research Jagakarsa Hospital has implemented the application of occupational safety and health standards of the hospital which include risk management, safety and security, occupational health services, Management of hazardous and toxic materials (B3) from aspects of occupational safety and health, fire prevention and control, management hospital infrastructure from aspects of occupational safety and health, management of medical equipment from aspects of occupational safety and health, preparedness to deal with emergencies or disasters have been implemented well by Jagakarsa Regional Hospital but in reality there are still some elements that have not been carried out according to the Occupational Safety and Health Standards diseases including risk management, fire control and prevention as well as hospital infrastructure.

Conclution: Jagakarsa Regional Hospital should complement the shortcomings in the field so that it can realize the dream of the hospital becoming a favorite and perfect hospital.
\end{abstract}

Keyword: The application of occupational safety and health. 


\section{Journal of

\section{Pendahuluan}

Rumah Sakit sebagai institusi pelayanan kesehatan bagi masyarakat merupakan tempat kerja yang memiliki risiko tinggi terhadap keselamatan dan kesehatan sumber daya manusia rumah sakit, pasien, pendamping pasien, pengunjung, mau pun lingkungan rumah sakit. Kesehatan menyatakan bahwa pengelola tempat kerja wajib melakukan segala bentuk upaya kesehatan melalui upaya pencegahan, peningkatan, pengobatan dan pemulihan bagi tenaga kerja. Dengan meningkatnya pemanfaatan Rumah Sakit oleh masyarakat maka kebutuhan terhadap penyelenggaraan K3RS semakin tinggi. ${ }^{1}$

Tenaga Kesehatan juga dinyatakan bahwa tenaga kesehatan dalam menjalankan praktik berhak memperoleh pelindungan atas keselamatan dan Kesehatan Kerja. Pengelola Rumah Sakit harus menjamin kesehatan dan keselamatan baik terhadap SDM Rumah Sakit, pasien, pendamping pasien, pengunjung, maupun lingkungan Rumah Sakit dari berbagai potensi bahaya di Rumah Sakit. Pengelola Rumah Sakit dituntut untuk melaksanakan upaya kesehatan dan keselamatan Kerja yang dilaksanakan secara terintegrasi, menyeluruh, dan berkesinambungan sehingga risiko terjadinya penyakit akibat kerja, kecelakaan kerja serta penyakit menular dan tidak menular lainnya di Rumah Sakit dapat dihindari. $^{2}$

Rumah Sakit dinyatakan bahwa dalam rangka peningkatan mutu pelayanan, Rumah Sakit wajib dilakukan akreditasi secara berkala minimal 3 (tiga) tahun sekali dimana unsur keselamatan dan Kesehatan Kerja termasuk sebagai salah satu hal yang dinilai di dalam akreditasi Rumah Sakit. Berdasarkan hal tersebut diatas, maka untuk melindungi sumber daya manusia Rumah Sakit, pasien, pendamping pasien, pengunjung, maupun lingkungan rumah sakit dari risiko kejadian keselamatan dan kesehatan kerja, diperlukan penyelenggaraan secara berkesinambungan. ${ }^{3}$

Program keselamatan dan kesehatan kerja (K3) di Indonesia yang menyatakan bahwa setiap tenaga kerja berhak mendapatkan perlindungan atas keselamatan dan kesehatan kerja (K3) dalam melakukan pekerjaan. Sementara itu untuk pengelolaan tempat kerja diatur oleh Undang Undang No 36 Tahun 2009 tentang Kesehatan pasal 165 menyebutkan bahwa "pengelola tempat kerja wajib melakukan segala bentuk upaya kesehatan melalui upaya pencegahan, peningkatan,

pengobatan dan pemulihan bagi tenaga kerja". Peraturan Menteri Kesehatan Republik Indonesia Nomor 66 tahun 2016 tentang Keselamatan dan Kesehatan Kerja Rumah Sakit menyatakan bahwa rumah sakit mempunyai risiko keselamatan dan kesehatan kerja yang spesifik sehingga perlu dikelola dengan baik agar menjadi tempat kerja yang sehat, aman dan nyaman. Rumah sakit menjadi salah satu tempat yang wajib menerapan standar kesehatan dan keselamatan kerja (SK3). Kesehatan dan keselamatan kerja merupakan upaya untuk memberikan jaminan keselamatan dan meningkatkan derajat kesehatan pekerja dengan cara pencegahan Kecelakaan Akibat Kerja (KAK) dan Penyakit Akibat Kerja (PAK) melalui upaya pengendalian bahaya ditempat kerja. Standar kesehatan dan keselamatan kerja penting dilaksanakan, mengingat kegiatan rumah sakit berpotensi menimbulkan bahaya fisik, kimia, biologi, ergonomik dan psikososial yang dapat membahayakan kesehatan dan keselamatan baik terhadap pekerja, pasien, pengunjung maupun masyarakat di lingkungan rumah sakit. ${ }^{4}$

Setiap jenis dan tempat pekerjaan memiliki risiko bahaya yang berbedabeda.Hal ini dipengaruhi oleh lokasi, proses kerja, material kerja, maupun alat-alat yang digunakan dalam melaksanakan pekerjaan.Salah satu pekerjaan yang memiliki risiko bahaya yang tinggi adalah rumah sakit. Pada umumnya masyarakat maupun pekerja di rumah sakit kurang menyadari berbagai potensi bahaya yang ada seperti adanya PAK di rumah sakit yang dapat menyerang semua tenaga kerja, baik tenaga medis maupun non medis. ${ }^{5}$ 


\section{Journal of

Menurut data Depkes, 35 juta pekerja kesehatan mengalami gangguan kesehatan, 3 juta pekerja terpajan patogen darah, 2 juta terpajan virus HBV, 0,9 juta terpajan virus HBS, 170.000 terpajan virus HIV/AIDS. Lebih dari $90 \%$ pekerja yang terpajan patogen tersebut terjadi di Negara berkembang, dan

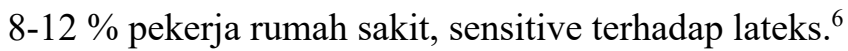

Penelitian yang dilakukan di RS Elim Rantepao Toraja Utara dan RSUD Lakipadada Makala Tana Toraja diperoleh hasil yaitu faktor yang berkontribusi dalam kejadian penyakit dan kecelakaan akibat kerja, yaitu faktor manusia (meliputi karakteristik umur, jenis kelamin, unit kerja, masa kerja petugas kesehatan dan perilaku yang tidak aman/berbahaya/ unsafe action dari tenaga kesehatan), faktor lingkungan yang tidak aman/berbahaya (unsafe condition) dan faktor manajemen K3 (upaya yang dilakukan dalam mengelola K3 untuk pencegahan penyakit dan kecelakaan akibat kerja. ${ }^{7}$

Penelitian lainnya di negara berkembang seperti India juga menyimpulkan hasil yang sama. Melaporkan dalam 1 tahun terakhir 5,4\% perawat rumah sakit di India mengalami luka akibat tertusuk jarum suntik, 7,4\% mengalami varises, dan 56,9\% mengalami stres kerja. Situasi menegangkan yang sering dialami perawat adalah tindakan kekerasan dan pelecehan dari pasien. Sementara itu data-data tentang kecelakaan kerja dan penyakit akibat kerja pada petugas kesehatan rumah sakit di Indonesia belum tercatat dan dilaporkan dengan baik, hal ini mengindikasikan penerapan Kesehatan dan Keselamatan Kerja di rumah sakit di Indonesia masih memerlukan upaya perbaikan. ${ }^{8}$

Perawat merupakan petugas kesehatan dengan presentasi terbesar dan memegang peranan penting dalam pemberian pelayanan kesehatan. WHO (mencatat, dari 39,47 juta petugas kesehatan di seluruh dunia, 66,7\%- nya adalah perawat. Di Indonesia, perawat juga merupakan bagian terbesar dari tenaga kesehatan yang bertugas di rumah sakit yaitu sekitar $47,08 \%$ dan paling banyak berinteraksi dengan pasien . Ada sekitar dua puluh tindakan keperawatan, delegasi, dan mandat yang dilakukan dan yang mempunyai potensi bahaya biologis, mekanik, ergonomik, dan fisik terutama pada pekerjaan mengangkat pasien, melakukan injeksi, menjahit luka, pemasangan infus, mengambil sampel darah, dan memasang kateter. ${ }^{9}$

Pada penelitian Dinar diketahui bahwa pegawai seksi nonmedis di RS PMI Bogor, dari hasil penelitian diketahui bahwa pegawai non medis yang baik terhadap K3 RS sebanyak 48,2 \% dan persepsi pegawai non medis yang kurang baik terhadap K3 RS sebanyak 51,8 \%. Sedangkan 4 pada penelitian Imar, diketahui bahwa pekerja di PT.Krama Yudha Ratu Motor,didalam penelitian ini presentase pekerja dengan persepsi baik sebanyak 47,3\% dan pekerja dengan persepsi kurang baik sebanyak 52,7 $\%$. Berdasarkan dari penelitian sebelumnya dapat diketahui bahwa masih banyak pekerja yang memiliki persepsi kurang dalam keselamatan dan kesehatan kerja. RSUD Jagakarsa adalah RS milik pemerintah yang bertipe D. Sebagai rumah sakit yang menjamin mutu pelayanannya yang berfokus kepada pasien , saat ini RSUD Jagakarsa telah terakreditasi 15 pelayanan serta memiliki sarana dan prasana 12 penunjang yaitu pada tahun 2015 dan 2019 yang dilakukan oleh Komite Akreditasi Rumah Sakit (KARS) . RSUD Jagakarsa pada saat itu juga menetapkan diri sebagai Green Hospital yaitu dengan menyatukan aspek sosial, estetika dan ekologi. Instalasi Kesehatan dan Keselamatan Kerja RSUD Jagakarsa juga terbilang masih baru di terbitkan karena K3RS di RSUD Jagakarsa berjalan di tahun 2019 sebelumnya K3 RSUD jagakarsa menjadi satu bagian atau satu instalasi dengan Kesehatan Lingkungan rumah sakit.

Melihat kondisi ini, jika kita berpedoman pada data-data tersebut, maka akan sulit menentukan RS mana yang memiliki angka kejadian kecelakaan dan penyakit akibat kerja yang tinggi. Sehingga penilaian awal dapat dilakukan pada kondisi RS dan perilaku kerja para petugasnya. Sebab kedua hal tersebut dapat menggambarkan risiko yang dapat ditimbulkannya. Dan salah satu RS yang penulis 


\section{Journal of

anggap perlu untuk diteliti upaya pencegahan kecelakaan, penyakit akibat kerja dan standart kesehatan dan keselamatan kerjanya. Maka dari itu peneliti tertarik untuk melakukan penelitian "Tinjauan Penerapan Standar Kesehatan dan Keselamatan Kerja berdasarkan Permenkes No. 66 Tahun 2016 di RSUD Jagakarsa Tahun 2019. Tujuan dari penelitian ini adalah untuk mengetahui penerapan keselamatan dan kesehatan kerja di RSUD jagakarsa tahun 2019.

\section{Metode}

Jenis penelitian yang digunakan bersifat kualitatif untuk menggambarkan Penerapan Standar Keselamatan dan Kesehatan Kerja di Rumah Sakit Umum Daerah Jagakarsa dasarkan Peraturan Menteri Kesehatan Republik Indonesia Nomor 66 Tahun 2016. Penelitian deskriptif kualitatif di tujukan untuk mendeskripsikan dan menggambarkan fenomena-fenoma yang ada,baik bersifat alamiah maupun rekayasa manusia,yang lebih memperhatikan mengenai karakteristik, kualitas, keterkaitan antar kegiatan. Selain itu, penelitian deskriptif tidak memberikan perlakuan, manipulasi atau pengubahan pada variabel-variabel yang diteliti, melainkan menggambarkan suatu kondisi yang apa adanya.Penelitian ini dilakukan dengan cara observasi, telaah dokumen, wawancara, dan dokumentasi. Penelitian ini dilakukan di RSUD Jagakarsa, sedangkan waktu pelaksanaan penelitian dan pengambilan data dilakukan pada bulan juli - September 2019.

Teknik sampling yang digunakan dalam penelitian ini adalah purposive sampling teknik pengambilan sampel sumber data dengan pertimbangan tertentu." Pertimbangan tertentu ini misalnya responden dianggap paling mengerti sehingga memudahkan peneliti menjelajahi situasi sosial yang di teliti. $^{10}$

Informan penelitian adalah objek penelitian yang dapat memberikan informasi yang diperlukan selama proses penelitian. Informan kunci (key informan) adalah mereka yang mengetahui dan memiliki berbagai informasi pokok yang diperlukan dalam proses penelitian. Adapun informan kunci dalam penelitian ini adalah pembuat kebijakan / penanggung jawab standar keselamatan dan kesehatan kerja di RSUD Jagakarsa. Kemudian sebagai informan pendukung peneliti mengambil satu (1) ketua P2K3, (1) Sekretaris P2K3 / ketua K3RS dan (3) anggota/team K3RS bagian koordinator standart kesehatan dan keselamatan kerja rumah sakit, dengan pertimbangan karena di anggap paling mengetahui, sehingga informan yang akan di dapatkan sesuai dengan yang diharapkan oleh peneliti.

Teknik pengumpulan data adalah langkah strategis dalam penelitian, karna tujuan penelitian adalah mendapatkan data. Tanpa mengetahui Teknik pengambilan data, maka peneliti tidak akan mendapatkan data yang memenuhi standar data yang diterapkan. Observasi merupakan suatu kegiatan mendapatkan informasi yang di perlukan untuk menyajikan gambaran nyata suatu peristiwa atau kejadian yang ada untuk menjawab pertanyaan penelitian,untuk mendukung memahami perilaku manusia dan untuk evaluasi yaitu melakukan pengukuran terhadap aspek-aspek tertentu yang tujuannya melihat umpan balik terhadap pengukuran tersebut. ${ }^{11}$

Peneliti melakukan pengamatan langsung di RSUD jagakarsa untuk mendapatkan data- data yang dibutuhkan. Dinyatakan baha dari wawancara yaitu percakapan dengan maksut tertentu. Percakapan dilakukan oleh dua pihak pewawancara yang mengajukan pertanyaan dan yang diwawancara yaitu yang memberikan jaaban atas pertanyaan tersebut. ${ }^{12}$ Wawancara ini dilakukan dengan wawancara terstruktur dilakukan melalui pertanyaan - pertanyaan yang telah disiapkan sesuai dengan permasalahan yang akan diteliti. Jenis wawancara yang digunkan adalah wawancara mendalam (In-Depth - Interview), yang dilakukan secara informal. Data yang diperoleh dari awancara mendalam ini terdiri dari kutipan langsung dari orang - orang tentang pengalaman, pengamatan, perasaan dan pengetahuanya. 


\section{Journal of

Dokumentasi adalah bahan tertulis atau film yang telah karena adanya permainan dari seorang peneliti. Teknik dokumentasi merupakan informasi yang berasal dari cacatan penting baik dari Lembaga atau organisasi maupun perorangan. Selain itu dokumentasi merupakan metode yang dilakukan untuk meningkatkan ketepatan pengamatan. Dokumentasi ini dilakukan untuk merekam pembicaraan dan juga dapat merekam suatu perbuatan yang dilakukan oleh responden pada saat wawancara. ${ }^{13}$

Dokumentasi juga dapat berupa gambar atau foto yang berhubungan dengan penelitian, dengan dokumentasi dapat membantu peneliti menyesuaikan antara kesesuaian data dengan kenyataanya. Dokumen bisa beragam bentuk, dari yang tertulis sederhana sampai yang lebih lengkap dan bahkan bisa berupa benda-benda sebagai peninggalan masa lampau. Data berupa gambar didapatkan pada saat kegiatan di lapangan dan telaah dokumen didapatkan dari dokumen-dokumen terkait standar kesehatan dan keselamatan kerja rumah sakit.

Instrument adalah alat pada waktu peneliti meggunakan suatu metode atau tehnik pengumpulan data. Instrument pengumpulan data adalah alat bantu yang digunakan sebagai sarana yang dapat diwujudkan dalam benda. Instrumen dalam penelitian ini adalah observasi, wawancara, telaah dokumen dan dokumentasi. Instrumen yang digunakan dalam penelitian ini adalah dengan menggunakan daftar wawancara. Dalam melakukan observasi langsung, daftar check list dan peneliti juga menggunakan kamera foto untuk melengkapi data penelitian.

Peneliti menggunakan triangulasi sebagai teknik untuk mengecek keabsahan data. Dimana dalam pengertiannya triangulasi adalah teknik pemeriksaan keabsahan data yang memanfaatkan sesuatu yang lain dalam membandingkan hasil wawancara terhadap objek penelitian. ${ }^{12}$ Triangulasi dapat dilakukan dengan menggunakan Teknik yang berbeda yaitu wawancara, observasi dan dokumen. Triangulasi ini selain digunakan untuk mengecek kebenaran data juga dilakukan untuk memperkuat data. Triangulasi juga dapat berguna untuk menyelidiki validitas tafsiran peneliti terhadap data, karena itu triangulasi bersifat reflektif. ${ }^{12}$

\section{Hasil dan Pembahasan}

\section{Penerapan Manajemen Resiko K3RS}

Berdasarkan hasil penelitian melalui wawancara, telaah dokumen dan dokumentasi yang telah dilakukan diperoleh hasil Seperti halnya dikatakan pihak RSUD Jagakarsa

"Adanya indentifikasi risiko bahaya terhadap semua kegiatan dengan menggunakan table Hirarc dan JSA (Joob Safety Analysis) di setiap unit dan ruangan yang menimbulkan bahaya risiko kerja. Rumah Sakit juga mempunyai regulasi yang mengatur tentang assesmen resiko pra kontruksi, Rumah Sakit melakukan assessmen risiko pra kontruksi bila ada rencana kontruksi renovasi atau pembongkaran bangunan, Rumah Sakit mengambil tindakan berdasarkan hasil assessmen risiko untuk meminimalkan risiko pembongkaran, kontruksi dan renovasi serta rumah sakit memastikan bahwa kepatuhan kontruktor di pantau, ditegakan dan didokumentasikan. Selain itu, dilakukan monitoring untuk identifiksai risiko pada setiap bulanya yang bertujuan untuk mengurangi risiko bahaya kerja di tempat kerja, dan jika terjadi incident akan di buatkan laporan dan dilaporkan ke direktur rumah sakit untuk dilakukan tidak lanjut".

Penerapan manajemen risiko K3RS di RSUD Jagakarsa didasarkan kepada Surat Keputusan Direktur Rumah Sakit Umum Daerah Jagakarsa Nomor 327 tentang program manajemen resiko di RSUD Jagakarsa tahun 2019. Maksud dan tujuan dari penerapan manajemen resiko di RSUD Jagakarsa adalahmenghimpun dan menyediakan data dan informasi kegiatan K3mendokumentasikan hasil-hasil pelaksanaan kegiatan K3, mencatat dan melaporkan kejadian setiap kasus K3 dan menyusun serta melaksanakan kegiatan K3 sehingga tercapainya kondisi rumah sakit yang selalu siap dalam mencegah, 


\section{Journal of

menangani, dan menghadapi kecelakaan akibat kerja, penyakit akibat kerja, bahaya kebakaran dan musibah massal berdasar data-data yang tercatat dan terlaporkan. Model manajemen risiko yang dilakukan oleh rumah Sakit Umum Daerah Jagakarsa mengacu padaPermenkes RI No. 66 Tahun 2016.

Dari hasil penelitian melalui wawancara, telaah dokumen dan dokumentasi RSUD Jagakarsa sudah melaksanakan manajemen resiko mulai dari persiapan sampai dengan pengendalian risiko K3RS. Namun dilihat dari program manajemen resiko pelaksanaan manajemen risiko sudah dilakukan oleh semua unit yang ada dirumah sakit hal ini dibuktikan dengan dokumen program manajemenrisiko telah ada di RSUD Jagakarsa. Namun pada kenyataanya tidak sepenuhnya program tersebut dilaksanakan.

Penelitian ini sejalan dengan penelitian Wilujeng Ika Kardina dkk, terkait manajemen risiko harus mengetahui aktifitas apa yang dilakukan dalam suatu pekerjaan dan uraian aktifitasnya, kemudian dilihat apakah uraian aktifitas tersebut dilakukan secara rutin atau tidak rutin. Pelaku aktifitas juga harus diketahui dalam form penilaian, lalu bahaya apa saja yang kemungkinan akan diterima oleh pelaku aktivitas. Di RSJ Grhasia D.I.Yogyakarta sendiri sudah menerapkan beberapa pengendalian aktivitas/pekerjaan hanya saja belum lengkap sehingga peneliti disini memberikan pengendalian tambahan agar penilaian risiko bisa di klasifikasikan tidak tinggi. ${ }^{14}$

Menurut peneliti manajemen risiko K3RS penting untuk mencegah terjadinya kecelakaan di tempat kerja yang dapat menimbulkan kerugian pada keselamatan dan kesehatan sumber daya manusia Rumah Sakit, pasien, pendamping pasien, pengunjung, maupun lingkungan Rumah Sakit.

\section{Penerapan Keselamatan Dan Keamanan Rumah Sakit}

Berdasarkan hasil penelitian melalui wawancara, telaah dokumen dan dokumentasi yang telah dilakukan diperoleh hasil Seperti halnya dikatakan pihak RSUD Jagakarsa

"adanya Identifikasi dan penilaian risiko yang komprehensif menyangkut keselamatan (lantai licin, terjebak lift, lift anjlok, dan lain-lain) dan keamanan (pencurian, penculikan bayi, kerusuhan, dan lainlain) dan juga sudah melakukanPemetaan area berisiko terjadinya gangguan keselamatan dan keamanan di Rumah Sakit contohnya sepertimemasang spanduk atau pamphlet larangan meroko di area yang mudah terbakar misalnya ruang gas medis, area parkir dan di seluruh lantai rumah sakit.Rumah sakit sudah memahami persyaratan, kewajiban dan kepatuhan secara konsisten dalam mengidentifikasi potensi bahaya dan risiko K3RS. hal ini terbukti adanya hasil inspeksi yang dilakukan"

Penerapan keselamatan dan keamanan di RSUD Jagakarsa didasarkan kepada Surat Keputusan Direktur Rumah Sakit Umum Daerah Jagakarsa Nomor 345 Tentang Pedoman Keselamatan Dan Keamanan di RSUD Jagakarsa Tahun 2019.Maksud dan tujuan dari penerapan keselamatan dan keamanan di RSUD Jagakarsa adalah meminimalkan dampak kontruksi, renovasi, atau penghancuran sehingga pelayanan pasien tetap terjaga kualitas dan keamanannya. Modelkeselamatan dan keamanan yang dilakukan oleh Rumah Sakit Umum Daerah Jagakarsa mengacu padaPermenkes RI No. 66 Tahun 2016. Identifikasi dan penilaian risiko keselamatan dan keamanan rumah sakit, Pemetaan area berisiko terjadinya gangguan keselamatan dan keamanan di Rumah Sakit.

Dari hasil penelitian melalui wawancara, telaah dokumen dan dokumentasi RSUD Jagakarsa sudah melaksanakan keselamatan dan keamanan mulai dari identifikasi dan penelitian risiko sampai pemetaan area berisiko di RSUD Jagakarsamenyeluruh dilakukan oleh semua unit yang ada dirumah sakit hal ini dibuktikan dengan adanya surat keputusan director RSUD Jagakarsanomor 345 tentang pedoman keselamatan dan keamanan di rsud jagakarsa.

Penelitian ini sejalan dengan penelitian sebelumnya yang dilakukan di RS Immanuel. Menurut penelitiansebelumnya keselamatan dan keamanan rumah sakit yang dilakukan di RS Immanuel, diantaranya adalah dengan menentukan zona bahaya di RS Immanuel, membuat jadual identifikasi dan pengukuran sumber bahaya dan risiko bahaya, serta melakukan rencana upaya pengendaliannya. Membuat jadual medical check up bagi karyawan RS dua kali dalam setahun setiap devisi, pembuatan dan pemasangan rambu-rambu keselamatan kerja, pelatihan out sourcing BHD dan tehnik kerja di RS Immanuel. ${ }^{15}$ 
Menurut peneliti Keselamatan Dan Keamanan Rumah Sakit penting untuk mencegah terjadinya hal yang tidak diinginkan yang dapat menimbulkan kerugian pada sumber daya manusia rumah sakit, pasien, pengunjung, pendamping pasien dan lingkungan rumah sakit.

\section{Penerapan Pelayanan Kesehatan Kerja}

Berdasarkan hasil penelitian melalui wawancara, telaah dokumen dan dokumentasi yang telah dilakukan diperoleh hasil Seperti halnya dikatakan pihak RSUD Jagakarsa

"sudah melaksanakan pelayanan kesehatan kerja mulai dari kegiatan promotif sampai unit layanan kesehatan kerja. Pelaksanaanpelayanan kesehatan kerja kerjadi RSUD Jagakarsamenyeluruh dilakukan oleh semua unit yang ada dirumah sakit hal ini dibuktikan dengan surat keputusandirectur RSUD Jagakarsa tentang manajemen fasilitas keselamatan kerja”.

Berdasarkan hasil penelitian melalui wawancara, telaah dokumen dan dokumentasi diperoleh adanya pelayanan kesehatan kerja secara maksimal dan sudah memiliki SOP tersendiri untuk segala kegiatan yang ada di rumah sakit. Penerapan pelayanan kesehatan kerja di RSUD Jagakarsa didasarkan kepada Peraturan Pemerintah Kesehatan Republik Indonesia Nomor 66 Tahun 2016. Kegiatan promotif, Kegiatan preventif, Kegiatan kuratif, Kegiatan rahabilitatif, Unit Layanan Kesehatan Kerja.

Penelitian ini sejalan dengan penelitian yang dilakukan Sri Nurfitriani pada tahun 2012 di RSUD Ajappange Soppeng penerapan standar pelayanan kesehatan kerja pencapaian standar sebesar 59,9\% ini masuk kedalam kategori terlaksana kurang baik. Penerapan standar pelayanan untuk keselamatan kerja pencapaian standar sebesar 78,6\% ini masuk kedalam kategori terlaksana sangat baik. Sosialisasi bertahap dibutuhkan di rumah sakit ini untuk memahamkan seluruh pekerja tentang pentingnya pelaksanaan K3 sehingga melaksanakan program dengan kemauan bukan karena hal itu aturan semata. ${ }^{16}$

Menurut peneliti, kinerja K3RS sudah dilaksanakan dengan baik dengan adanya SOP dan beberapa dokumen terkait pelayanan kesehatan kerja disetiap unit pelayanan kerja.

\section{Penerapan Pengelolaan Bahan Berbahaya dan Beracun (B3) dari Aspek Keselamatan dan Kesehatan Kerja}

Berdasarkan hasil penelitian melalui wawancara, telaah dokumen dan dokumentasi yang telah dilakukan diperoleh hasil Seperti halnya dikatakan pihak RSUD Jagakarsa

"Adanya SOP tentang B3, MSDS, penempatan B3 sudah sesuai dan berlebel serta melakukan identifikasidi setiap unit kerja, setiap kariyawan di RSUD Jagakarsa memmaparkan tentang B3 setiap bulannya dan juga rumah sakit mengirim kariyawan yang bersangkutan dan berwenang di B3 untuk pelatihan sesuai dengan Permenkes No.66 Tahun 2106".

Penerapan Pengelolaan Bahan Berbahaya dan Beracun (B3) dari Aspek Keselamatan dan Kesehatan kerjadi RSUD Jagakarsa didasarkan kepada Surat Keputusan Direktur Rumah Sakit Umum Daerah Jagakarsa Nomor 07 tentang keselamatan dan kesehatan kerjadi RSUD Jagakarsa tahun 2019. Maksud dan tujuan dari penerapan Pengelolaan Bahan Berbahaya dan Beracun (B3) dari Aspek Keselamatan dan Kesehatan kerjasebagai penunjuk penanggulangan apabila terjadi kontaminasi bahan berbahaya, agar mengetahui bahaya yang timbul apabila terjadi kontaminasi, memperkecil dampak yang timbul akibat kecelakaan kerja. ModelPengelolaan Bahan Berbahaya dan Beracun (B3) dari Aspek Keselamatan dan Kesehatan kerjadilakukan oleh rumah sakit umum daerah jagakarsa menurut Permenkes RI.No. 66 tahun 2016. Identifikasi dan Inventarisasi Bahan Berbahaya dan Beracun (B3), Penanganan Keadaan Darurat Bahan Berbahaya dan Beracun (B3).

Dari hasil penelitian melalui wawancara, telaah dokumen dan dokumentasi RSUD Jagakarsa sudah melaksanakan Pengelolaan Bahan Berbahaya dan Beracun (B3) dari Aspek Keselamatan dan Kesehatan kerja mulai dari identifikasisampai dengan Penanganan Keadaan Darurat Bahan Berbahaya dan Beracun (B3). pelaksanaan Pengelolaan Bahan Berbahaya dan Beracun (B3) dari Aspek Keselamatan dan Kesehatan kerjasudah menyeluruh dilakukan oleh semua unit yang ada dirumah sakit. Hal ini dibuktikan dengan dokumen panduan Pengelolaan Bahan Berbahaya dan Beracun (B3) dari Aspek Keselamatan dan Kesehatan kerjatelah ada di RSUD Jagakarsa. 
Penelitian ini sejalan dengan penelitian Sri Eka Dewi FS pada Tahun 2018. Sri Eka Dewi FS pada Tahun 2018, limbah B3 merupakan zat sisa suatu usaha/kegiatan yang karena sifat, konsentrasi, dan jumlahnya, baik langsung dan tidak langsung dapat mencemarkan dan merusak lingkungan hidup. Jika tidak dilakukan pengolahan, limbah B3 dapat mengubah kualitas lingkungan. Pengolahan dimaksud adalah proses mengubah jenis, jumlah, dan karakteristik limbah menjadi tidak berbahaya dan tidak beracun. ${ }^{17}$

Menurut peneliti, kinerja K3RS sudah dilaksanakan dengan baik dengan adanya SPO serta dokumen terkait lainya tentang B3, MSDS, penempatan B3 sesuai dengan Permenkes No.66 Tahun 2016.

\section{Penerapan Pencegahan Dan Pengendalian Kebakaran}

Berdasarkan hasil penelitian melalui wawancara, telaah dokumen dan dokumentasi yang telah dilakukan diperoleh hasil Seperti halnya dikatakan pihak RSUD Jagakarsa

"Identifikasi sampai dengan simulasi kebakaran. Namun dilihat dari panduan pencegahan dan pengendalian kebakaran pelaksanaan sudah menyeluruh dilakukan oleh semua unit yang ada dirumah sakit . hal ini dibuktikan dengan dokumen pencegahan dan pengendalian kebakaran yang ada di RSUD Jagakarsa. Namun pada kenyataanya tidak sepenuhnya program tersebut dilaksanakan".

Penerapan keselamatan dan keamanan di RSUD Jagakarsa didasarkan kepada Surat Keputusan Direktur rumah sakit umum daerah jagakarsa tentang program pencegahan dan pengendalian kebakaran di RSUD Jagakarsa tahun 2019.Maksud dan tujuan dari programpencegahan dan pengendalian kebakaran di rsud Jagakarsa Memastikan sumber daya manusia Rumah Sakit, pasien, pendamping pasien, pengunjung, maupun lingkungan Rumah Sakit aman dan selamat dari api dan asap. Memastikan asset/properti Rumah Sakit (bangunan, peralatan, dokumen penting, sarana) yang aman dan selamat dari api dan asap. Modelpencegahan dan pengendalian kebakaran yang dilakukan oleh rumah sakit umum daerah jagakarsa mengacu pada permenkesRI No. 66 Tahun 2016. Identifikasi Area Berisiko Bahaya Kebakaran dan Ledakan, Pemetaan Area Berisiko Tinggi Kebakaran dan Ledakan, Pengurangan Risiko Bahaya Kebakaran dan Ledakan, Pengendalian Kebakaran, Simulasi Kebakaran.

Penelitian ini sejalan dengan ketetapan Menteri Pekerjaan Umum terkait penggolongan risikokebakaran.Menurut penggolonganrisikokebakaranolehMenteri PekerjaanUmum, rumah sakitsendiritergolong risikokebakaran ,artinyatermasukkategoricukuprawan. Sehinggadapat disimpulkanrumahsakittergolongkategoribangunanyangberesikokebakaran dilihat dari banyaknya sumberpotensi bahaya dan penghuninya. dengan demikian keberadaan peralatan pemadam seperti sprinkler, APAR, hydrant dan alat pendeteksi asap atau suhu sangatlah penting. Selain itu keberadaan suatu manajemen penanggulangan keberadaan sangat dibutuhkan ketika bencana kebakaran sudah terjadi. ${ }^{18}$

Menurut peneliti, kinerja K3RS sudah dilaksanakan dengan baik dengan adanya evaluasi hasil inspeksi berkala terkait penanggulangan kebakaran akan tetapi sangat disayangkan rumah sakit. Berikut beberapa dokumen terkait pencegahan dan pengendaliandi RSUD Jagakarsa.

\section{Penerapan Pengelolaan Prasarana Rumah Sakit dari Aspek Keselamatan dan Kesehatan Kerja}

Berdasarkan hasil penelitian melalui wawancara, telaah dokumen dan dokumentasi yang telah dilakukan diperoleh hasil Seperti halnya dikatakan pihak RSUD Jagakarsa

"Adanya panduan serta program penggunaan listrik, penggunaan air, tata udara yang cukup, penggunaan genset, penggunaan peralatan medis, adanya pengelolaan peralatan medis dan adanya pengawasan dalam pengolahan peralatan medis yang dilakukan dengan baik sesuai dengan undangundang".

Penerapan Pengelolaan Prasarana Rumah Sakit Dari Aspek Keselamatan dan Kesehatan Kerja di RSUD Jagakarsa di RSUD Jagakarsa didasarkan kepada Peraturan Mentri Pekerjaan Umum Nomor 24 Tahun 2008 di Rumah Sakit Umum Daerah Jagakarsa tentang pedoman perawatan dan pemeliharaan baguanan Gedung di RSUD Jagakarsa Tahun 2019.Maksud dan tujuan dari pedoman perawatan dan pemeliharaan bagunan gedungdi RSUD Jagakarsa adalah untuk dapat terwujudnya bangunan gedung 


\section{Journal of

sesuai fungsi yang ditetapkan dan yang memenuhi persyaratan teknis yaitu keselamatan, kesehatan, kenyamanan, dan kemudahan serta kelestarian lingkungan. ModelPengelolaan Prasarana Rumah Sakit Dari Aspek Keselamatan dan Kesehatan Kerja di RSUD Jagakarsa yang dilakukan oleh rumah sakit umum daerah jagakarsa mengacu padapermenkes RI No. 66 tahun 2016. Memastikan adanya daftar inventaris komponen-komponen sistem utilitasnya dan memetakan pendistribusiannya. Memastikan dilakukan kegiatan pemeriksaan, pengujian dan pemeliharaan terhadap semua komponen-komponen sistem utilitas yang beroperasi, semua komponennya ditingkatkan bila perlu. Mengidentifikasi jangka waktu untuk pemeriksaan, pengujian, dan pemeliharaan semua komponen-komponen sistem utilitas yang beroperasi di dalam daftar inventaris, berdasarkan kriteria seperti rekomendasi produsen, tingkat risiko, dan pengalaman Rumah Sakit. Memberikan label pada tuas-tuas kontrol sistem utilitas untuk membantu pemadaman darurat secara keseluruhan atau sebagian. Memastikan dilakukannya dokumentasi setiap kegiatan sistem utilitas.

Dari hasil penelitian melalui wawancara, telaah dokumen dan dokumentasi RSUD Jagakarsa sudah melaksanakan Pengelolaan Peralatan Medis Dari Aspek Keselamatan Dan Kesehatan Kerja mulai dari Memastikan adanya daftar inventaris komponen-komponen sistem utilitasnya dan memetakan pendistribusiannya sampai dengan Memastikan dilakukannya dokumentasi setiap kegiatan sistem utilitas. Dilihat dari program Pengelolaan Peralatan Medis Dari Aspek Keselamatan Dan Kesehatan Kerja pelaksanaan sudah menyeluruh dilakukan oleh semua unit yang ada dirumah sakit . hal ini dibuktikan dengan dokumen Pengelolaan Peralatan Medis Dari Aspek Keselamatan Dan Kesehatan Kerja yang ada di RSUD Jagakarsa.

Penelitian ini sejalan dengan penelitian Kuntjoro Adi Purjanto. Setiap rumah sakit dan pelayanan kesehatan memiliki interaksi yang tidak mudah dan memiliki masalah seperti potensi-potensi kekeliruan, potensi Kecelakaan Tidak Diharapkan (KTD), dan potensi apapun yang terkait dengan risiko-risiko yang akan didapatkan oleh pasien termasuk karyawan serta lingkungannya. Dalam uapay menekan risiko kecelakaan sekecil mungkin pada pasien, maka manajemen risiko diberlakukan. Penyebab Kecelakaan Tidak Diharapkan tersebut meliputi alat kesehatan yang tidak sesuai pelayanan dan kurangnya pelatihan pada Sumber Daya Manusia sehingga sangat diperlukan pengelolaan sarana prasarana yang aman, fungsional dan mendukung bagi pasien, keluarga, staf, pengunjung dan lingkungan rumah sakit. ${ }^{19}$

Menurut peneliti, kinerja K3RS sudah dilaksanakan dengan baik dengan adanya evaluasi hasil perbaikan, pemeriksaan berkala terkait pengolahan peralatan prasarana rumah sakit aspek keselamatan dan kesehatan kerja.berikut beberapa dokumen terkait hasil penelitian di RSUD Jagakarsa.

\section{Pengolahan Peralatan Medis dari Aspek Keselamatan dan Kesehatan Kerja}

Berdasarkan hasil penelitian melalui wawancara, telaah dokumen dan dokumentasi yang telah dilakukan diperoleh hasil Seperti halnya dikatakan pihak RSUD Jagakarsa

"Adanya pemberian informasi dasar untuk pengelolaan asset, termasuk membantu penjadualan pemeliharaan preventif, pemeliharan, perbaikan dan pemeriksaan berkala terkait pengolahan peralatan medis dari aspek keselamatan dan kesehatan kerja, rumah sakit memberikan tanda untuk asset yang tidak digunakan dan yang digunakan untuk asset yang tidak digunakan akan dipindahkan langsung ke ruang gudang atau diberi tanda $X$ untuk mencegah terjadinya kesalah pahaman menggunakan alat".

Penerapan Pengelolaan Peralatan Medis Dari Aspek Keselamatan Dan Kesehatan Kerja di RSUD Jagakarsa didasarkan kepada Surat Keputusan Direktur Rumah Sakit Umum Daerah Jagakarsa Nomor 21 Tentang Manajemen Fasilitas Keselamatan di RSUD Jagakarsa tahun 2019.Maksud dan tujuan dari sistem manajemen keselamatan di RSUD Jagakarsa adalah melakukan pemeriksaan peralatan medis sesuai dengan penggunaan dan ketentuan pabrik, melaksanakan pemeliharaan preventif dan kalibrasi. Model Pengelolaan Peralatan Medis Dari Aspek Keselamatan Dan Kesehatan Kerja di RSUD Jagakarsa yang dilakukan oleh Rumah Sakit Umum No. 66 Tahun 2016. Memastikan tersedianya daftar inventaris seluruh peralatan medis. Memastikan penandaan pada peralatan medis yang digunakan dan yang tidak digunakan. Memastikan dilaksanakanya Inspeksi berkala. Memastikan dilakukan uji fungsi dan uji coba 
peralatan. Memastikan dilakukan pemeliharaan promotif dan pemeliharaan terencana pada peralatan medis. Memastikan petugas yang memelihara dan menggunakan peralatan medis kompeten dan terlatih.

Dari hasil penelitian melalui wawancara, telaah dokumen dan dokumentasi RSUD Jagakarsa sudah melaksanakan Pengelolaan Peralatan Medis Dari Aspek Keselamatan Dan Kesehatan Kerja di RSUD Jagakarsa mulai dari Memastikan tersedianya daftar inventaris seluruh peralatan medis sampai dengan Memastikan petugas yang memelihara dan menggunakan peralatan medis kompeten dan terlatih. Dilihat dari pelaksanaan Pengelolaan Peralatan Medis Dari Aspek Keselamatan Dan Kesehatan Kerja di RSUD Jagakarsa sudah menyeluruh dilakukan oleh semua unit yang ada dirumah sakit . hal ini dibuktikan dengan dokumen Pengelolaan Peralatan Medis Dari Aspek Keselamatan Dan Kesehatan Kerja yang ada di RSUD Jagakarsa.

Penelitian ini sejalan dengan penelitian Sugiarto Pengelolaan peralatan medis dari aspek keselamatan dan kesehatan kerja merupakan salah satu factor penting dalam penyelenggaraan pelayanan kesehatan, baik di rumah sakit maupun di fasilitas pelayanan Kesehatan lainnya. Guna mencapai kondisi maupun fungsi peralatan kesehatan yang baik serta dapat mendukung pelayanan kesehatan maka perlu adanya pengelolaan peralatan medis dari aspek keselamatan dan kesehatan kerja. ${ }^{20}$

Menurut peneliti, kinerja K3RS sudah dilaksanakan dengan baik dengan adanya evaluasi hasil perbaikan, pemeriksaan berkala terkait pengolahan peralatan medis dari aspek keselamatan dan kesehatan kerja. Berdasarkan hasil penelitian tersebut didaptkan dokumen terkait Pengolahan Peralatan Medis Dari Aspek Keselamatan dan Kesehatan Kerja di RSUD Jagakarsa.

\section{Kesiapsiagaan Menghadapi Kondisi Darurat atau Bencana}

Berdasarkan hasil penelitian melalui wawancara, telaah dokumen dan dokumentasi yang telah dilakukan diperoleh hasil Seperti halnya dikatakan pihak RSUD Jagakarsa

"Adanya penyediaan alat / sarana dan prosedur keadaan darurat berdasarkan hasil indentifikasi dan diuji serta ditinjau secara rutin oleh petugas yang berkompeten dan berwenang, dilakukan pengecekan pada peralatan, dan sistem tanda bahaya keadaan darurat yang disediakan, diperiksa, diuji serta dipelihara secara berkalasetiap 1 bulan sekali sesuai dengan peraturan perundang-undangan. Rumah mempunyai team tanggap darurat bencana dan selalu melakukan uji coba (simulasi) keadaan darurat bencana setiap 1 tahun sekali sesuai dengan SOP yang ada di rumah sakit”.

Penerapan Kesiapsiagaan Menghadapi Kondisi Darurat Bencana di RSUD Jagakarsa didasarkan kepada Surat Keputusan Direktur Rumah Sakit Umum Daerah Jagakarsa tentang program penanggulangan bencana di RSUD Jagakarsa Tahun 2019.Maksud dan tujuan dari program penanggulangan bencana di RSUD Jagakarsa adalah untuk mengurangi kerugian jika terjadi bencana seperti bencana alam atau bencana yang ditimbulkan oleh kecerobohan manusianya seperti bencana kebakaran, penculikan bayi dll.. Model kesiapsiagaan menghadapi kondisi darurat bencana di RSUD Jagakarsa yang dilakukan oleh Rumah Sakit Umum Daerah Jagakarsa mengacu padat Permenkes RI No. 66 Tahun 2016. Identifikasi risiko kondisi darurat atau bencana. Identifikasi risiko kondisi darurat atau bencana.

Pengendalian kondisi darurat atau bencana. Simulasi kondisi darurat atau bencana.

Dari hasil penelitian melalui wawancara, telaah dokumen dan dokumentasi RSUD Jagakarsa sudah melaksanakan kesiapsiagaan kondisi darurat atau bencanadi RSUD Jagakarsa mulai dari identifikasi risiko darurat atau bencana sampai dengan simulasi kondisi darurat atau bencana. Dilihat dari pelaksanaan program penanggulangan bencana di RSUD Jagakarsa sudah menyeluruh dilakukan oleh semua unit yang ada dirumah sakit . hal ini dibuktikan dengan dokumen program penanggulangan bencana yang ada di RSUD Jagakarsa.

Penelitian ini sejalan dengan penelitian Talati dkk bencana menimbulkan tantangan unik bagi setiap instansi pelayanan medis dalam hal infrastruktur, kapasitas dan kesiapan dari sudut pandang Rumah Sakit. Suatu bencana ada saat jumlah korban jauh melebihi kemampuan dari jumlah tenaga medis untuk memberikan perawatan darurat sehinga Rumah Sakit terpaksa menerapkan sumber tambahan untuk perawatan kepada sejumlah besar korban. Bencana yang terjadi di rumah sakit dalam 


\section{Journal of

hal ini berkaitan dengan bencana internal maupun bencana yang juga memberi ancaman bagi masyarakat umum. Bencana tersebut merupakan bagian dari kondisi kegawat daruratan yang mungkin dialami rumah sakit sehingga dapat menimbulkan kerugian fisik, material, jiwa, bagi sumber daya manusia Rumah Sakit, pasien, pendamping pasien, dan pengunjung yang dapat mengganggu operasional serta menyebabkan kerusakan lingkungan ataupun mengancam finansial dan citra Rumah Sakit. ${ }^{21}$

Menurut peneliti, peninjauan dan peningkatan kinerja K3RS sudah dilaksanakan dengan baik dengan adanya evaluasi hasil inspeksi dan pelatihan yang diberikan kepada anggota team tanggap darurat bencana. Berdasarkan hasil penelitian tersebut didaptkan dokumen terkait Kesiapsiagaan Menghadapi Kondisi Darurat Atau Bencana di RSUD Jagakarsa.

\section{Kesimpulan}

Berdasarkan hasil penelitian dan pembahasannya, Penerapan Standar Keselamatan dan Kesehatan Kerja Rumah Sakit (K3RS) di RSUD Jagakarsa, maka dapat diambil suatu kesimpulan diantaranya Penerapan manajemen resiko, Keselamatan dan Keamanan Rumah Sakit, Pelayanan Kesehatan kerja rumah, Pengelolaan Bahan Berbahaya dan Beracun (B3) dari Aspek Keselamatan dan Kesehatan Kerja, Pencegahan dan pengendalian kebakaran, Pengelolaan Prasarana Rumah Sakit dari Aspek Keselamatan dan Kesehatan Kerja, Pengolahan Peralatan Medis dari Aspek Keselamatan dan Kesehatan Kerja, Pengolahan Peralatan Medis dari Aspek Keselamatan dan Kesehatan Kerja diketahui bahwa Rumah Sakit sudah melakukan penerapan sesuai dengan Permenkes No.66 Tahun 2106.

Berdasarkan hasil penelitian yang telah dilakukan, Penerapan Standar Keselamatan dan Kesehatan Kerja Rumah Sakit sudah dilakukan RSUD Jagakarsa. Namun pada kenyataanya belum terlaksana dengan maksimal. Sebaiknya RSUD Jagakarsa melengkapi kekurangan di lapangan yang meliputi dibagian sarana prasarana, manajemen risiko, pencegahan dan pengendalian kebakaran.

\section{Konflik Kepentingan}

\section{Ucapan Terima Kasih}

\section{Pendanaan}

\section{References}

1. Undang-Undang RI. Republik Indonesia Nomor 36 Tahun 2009 Tentang Kesehatan. Jakarta: UU RI: 2009.

2. Undang-Undang Republik Indonesia Nomor 36 Tahun 2014 tentang tenaga Kesehatan. Dipetik Mei 06, 2016, dari: www.kemenkopmk.go.id/content/uu- nomor-36-tahun-2014.

3. Undang-Undang RI. Nomor 44 Tahun 2009 tentang Rumah Sakit. Jakarta: Undang-Undang RI; 2009.

4. Rahmawati. Penerapan Standar Keselamatan Dan Kesehatan Kerja. 2017.

5. Anies. Penyakit Akibat Kerja. Jakarta: Alexmedia Komputindo; 2005.

6. Depkes RI. Sistem Kesehatan Nasional. Jakarta: Depkes RI; 2009.

7. Martina. Studi Kecelakaan Kerja Pada Petugas RS Elim Rantepao Dan RSUD Lakipada Makale Kabupaten Tana Toraja.Jurnal.Kesehatan Dan Keselamatan Kerja FKM Universitas Hasanudin Makassar.

8. Iwan MR. Analisis Risiko Kesehatan Dan Keselamatan Kerja (K3) Pada Perawat; 2018.

9. WHO. Organization WH. A global brief on Hypertension: silent killer, global public health crises (World Health Day 2013). Geneva: WHO; 2013. 


\section{Journal of

10. Sugiyono. Metode Penelitian Kuantitatif Kualitataif Dan Kombinasi (Mixed Methods). Bandung: Alfabeta; 2016.

11. Sujarweni. Metode Penelitian: Lengkap, Praktis Dan Mudah Dipahami. Yogyakarta: Pustaka Baru Press; 2004.

12. Moleong. Metode Penelitian Kualitatif. Bandung: Remaja Rosdakarya; 2009.

13. Hamidi. Metode Penelitian Kualitatif. Malang. UMM Prsess; 2010.

14. Wilujeng IK dkk. Manajemen Risiko Keselamatan Dan Kesehatan Kerja (K3) Di Rumah Sakit Jiwa Grhasia D.I. Yogyakarta; 2019.

15. Novie EM. Penerapan Sistem Manajemen K3RS Rumah Sakit Imanuel Bandung. Jurnal Kesehatan Kartika; 2007.

16. Nurfitriani S. Penerapan Standar Kesehatan Dan Keselamatan Kerja Rumah Sakit (K3RS) RSUD Ajappange Soppeng; 2012.

17. Sri Eka Dewi FS. Kurangi Pencemaran, Limbah B3 'Iron Slag' Diolah Jadi Batu Bata Ramah Lingkungan Tahun 2018.

18. Ramli S. Petunjuk Praktis Manajemen Kebakaran Fire Management. Jakarta: Dian Rakyat; 2010.

19. Kuntjoro AP. Pelayanan Kesehatan rumah sakit; 2018.

20. Sugiart. Pedoman Pengelolaan Peralatan Kesehatan Direktorat Bina Pelayanan Penunjang Medik Dan Sarana Kesehatan; 2015.

21. Talati dkk. Studi Kualitatif Kesiapsiagaan Tim Komite Bencana Rumah Sakit Pku Muhammadiyah Bantul Dalam Menghadapi Bencana Vol. 2, No. 1, April 2018, Pp. 8-15 Http://Journal.Stikessuryaglobal.Ac.Id. 